This is the author's post-print of an article publishes as: Oliver Dietrich, Learning from 'scrap' about Late Bronze Age hoarding practices. A biographical approach to individual acts of dedication in large metal hoards. European Journal of Archaeology 17, 3 2014, 468-486. DOI 10.1179/1461957114Y.0000000061

\title{
Learning from 'scrap' about Late Bronze Age hoarding practices. A biographical approach to individual acts of dedication in large metal hoards of the Carpathian Basin
}

\author{
Oliver Dietrich
}

German Archaeological Institute, Berlin, Germany

Hoard finds appear throughout the European Bronze Age with distinct chronological and chorological peaks. While there is some consensus on seeing hoards as an expression of cultic behaviour, especially the large 'scrap metal' hoards still provoke interpretations as raw material collected for recycling. With socketed axes whose sockets were intentionally filled with deliberately fragmented metalwork, S. Hansen (1996-1998) has pointed out a group of finds that could be crucial to a better understanding of 'scrap' hoards. Using the finds from the Carpathian Basin as a case study, a twofold biographical approach is applied to this group. A close look at the complex use-life of the objects themselves, as well as an attempt at re-integrating them into the local history of hoarding, leads to the conclusion that they constitute single acts of dedication in larger contexts. 'Scrap hoards' can thus be understood as long-term accumulations of votive objects and can be integrated into the social practice of Bronze Age hoarding.

Keywords: Bronze Age, Carpathian Basin, Fragmentation, hoards, socketed axes, object combinations

\section{Introduction: Bronze Age hoards — cultic or profane, or both?}

The meaning of Bronze Age hoard finds has been discussed controversially for over 150 years, usually fluctuating between the polar opposites of profane metal collections and votive offerings (cf. early contributions by Thomsen, 1843-1845; Worsaae, 1867; Müller, 1886). D.R. Fontijn (2002: Table 2.3) has recently shown that the arguments used in this debate have been astonishingly persistent. They can be summarized in two large groups. One addresses the circumstances of deposition, with a focus on the environment in which the finds were placed. Wet and swampy contexts are thought to indicate ritual finds, as the artefacts are nonretrievable and the deposition definite. Hoards from dry land are seen as retrievable and thus profane in nature. There are obvious problems with this line of argumentation, as, for example, changes of the landscape have to be considered and hoards from wet places may not be as non-retrievable as archaeologists sometimes think (Geißlinger, 2004). On the other hand, hoards on dry land may well have been sacrosanct and definite by criteria that left no trace in the archaeological record (on the problems of the wet versus dry argument, see the recent contribution by Bradley, 2013: 124-125).

The other, and more rewarding, approach is to find structure in the apparently unordered finds. Several studies have shown that hoards are constituted due to regionally and chronologically differing rules on the categories and conditions of objects included, the arrangement of objects within the hoard, the placement of hoards in the landscape, and others more (cf. von Brunn, 1980; Geißlinger, 1984; Willroth, 1985; Hansen, 1994; Sommerfeld, 1994; Soroceanu, 1995; Kristiansen, 1996; Hänsel \& Hänsel, 1997; Fontijn, 2002; Hansen, 2005; Maraszek, 2006; Vachta, 2008; Čivilyté, 2009; Hansen et al. (eds.), 2012). Certain classes of objects are obviously restricted to certain contexts; often things deposited in graves will differ in type and function from those in hoards, while none of these sources represents the full range of objects in circulation (Hundt, 1955; Eggers, 1959: 264-68, 276-97; Hansen, 1994: 316-18, 388-90; Needham, 2007: 279-80). Especially the work of the last 20 years has thus led to a far-reaching consensus in addressing the hoarding phenomenon as a social praxis 
This is the author's post-print of an article publishes as: Oliver Dietrich, Learning from 'scrap' about Late Bronze Age hoarding practices. A biographical approach to individual acts of dedication in large metal hoards. European Journal of Archaeology 17, 3 2014, 468-486. DOI 10.1179/1461957114Y.0000000061

rooted in religious beliefs. Another important basis for this paradigm shift is the seminal work by M. Mauss (1990) on gift exchange.

Mauss (1990: 22-25) started from F. Boas' (1925) observations on the post-colonial potlatch, a festive competition of the societies of the North American Pacific coast, especially the Kwakiutl, on who could give away the most valuable gifts. The winners of these competitions earned an important social position, or, to put it in the words of P. Bourdieu (2012: 335-77), symbolic capital, recognition, prestige and a 'gentle and cloaked form' of power. At one point, the accumulated symbolic capital transforms into social capital, i.e. possibilities of acting, and economic capital, e.g. the disposal over the work force of other members of the society (cf. Hansen, 2005: 226). Giving thus serves to generate social power and influence. Mauss (1990: 50-77) saw gift exchange as a generalized phenomenon in many archaic societies, which worked on the basis of meaningful things. His best known example for those meaningful things is the kula-ring of the Trobriand Islands described first by B. Malinowski (1922). Among the inhabitants of these islands, necklaces and bracelets which carried names and biographies (Mauss, 1990: 60-61) were exchanged in a reciprocal framework of apparently voluntary giving, taking and returning of gifts, which in reality are regulated by social constraint and rules (Mauss, 1990: 22, 27-36). Although some of Mauss' considerations have seen critique (Godelier, 1999), his basic observations remain valid. W. Burkert (1998: 158-88) and M. Godelier (1999: 46-49) have especially elaborated on Mauss' (1990: 39-49) observation that gift exchange does not only take place between men, but also between humans and supernatural powers. Metal accumulations removed from the reach of humans can thus be seen as gifts to the gods, exchanged on the principle of do ut des, i.e. 'I give and you give in return' (e.g. Sommerfeld, 1994: 266; Hänsel, 1997).

Reluctance against this model has been expressed especially with regard to the socalled 'scrap hoards' (e.g. Bradley, 1990; Fontijn, 2002; Huth, 2008), big accumulations of heavily fragmented metalwork and raw materials. Earliest evidence for such finds comes from western Hungary with the hoards of the so-called Koszider type around 1600 BC (Hansen, 2005: 218-21). Roughly at the same time the scrap hoards of the Bühl-Ackenbach horizon in the northern Circum-Alpine region appear (Rittershofer, 1983; Brandherm, 2004), while in large parts of Europe hoards of fragmented metalwork are a characteristic phenomenon of the Late Bronze Age (LBA) (Hansen, 1994; 2005). In the following, no complete re-discussion of the hoarding phenomenon in view of Mauss' considerations is intended. Rather the case will be made that 'scrap' hoards do not pose a counterargument to this line of interpretation.

\section{How to make sense of 'scrap'}

Especially in the western European tradition of archaeological thought, accumulations of fragmented metalwork have been taken as evidence for secular hoarding motives. J. Evans (1881: 456-59) was the first to develop a methodological framework for interpreting hoard finds from the British Isles. He distinguished 'personal hoards', individual belongings buried in troubled times to be retrieved later, 'merchant's hoards' characterized by largely new objects, and 'founder's hoards', raw material collections meant for recycling, including old and broken objects as well as casting refuse. V.G. Childe (1930: 43-45) added 'votive hoards' later on to this classification, and several studies have aimed at modifying the image (e.g. Needham, 2001; 2007; Brück, 2006; Turner, 2010: 93-100; Bradley, 2013). But still the profane line of interpretation, especially for the 'scrap' hoards, has been quite persistent (Bradley, 1990: 123; Huth, 1997; 2008; Malim, 2010; general characterizations of the debate e.g. in Bradley, 2013; Brück, 2006: 305-06; Turner, 2010: 18-22, 105-06; compare also the entries of the Portable Antiquities Scheme where fragmentation frequently results in the attribute 'founder's hoard'). 
This is the author's post-print of an article publishes as: Oliver Dietrich, Learning from 'scrap' about Late Bronze Age hoarding practices. A biographical approach to individual acts of dedication in large metal hoards. European Journal of Archaeology 17, 3 2014, 468-486. DOI 10.1179/1461957114Y.0000000061

Fontijn (2002: 25-26) has translated this distinction also into the debate on hoards as evidence of gift exchange. In his eyes, 'ritual hoards' are constituted of complete and used objects, that have accumulated meaning throughout their use-life and are part of gift exchange in the sense of Mauss. 'Scrap hoards' on the other hand would be formed of objects that are commodities and have lost their individuality and meaning by being reduced to scrap. Although not stated explicitly, at the basis of such assumptions lies the modern western preconception to regard broken things as refuse, in the best case as raw material, but anyway stripped of whatever meaning they once may have possessed. That this concept may not be valid for prehistory has been shown in detail by J. Chapman (2000).

Several approaches have been pursued to integrate scrap hoards in the larger phenomenon of Bronze Age hoarding. C. Sommerfeld (1994) saw the fragmentation of sickles as an intentional act aiming at the production of fragments standardized in weight, which he believed to have a pre-monetary character. In Sommerfeld's interpretation, fragmentation aims at the value of the metal as a gift to the gods. While fragmentation of bronze artefacts has been shown to be intentional in many cases and to result in recurring patterns (e.g. Wanzek, 1989: 67, 230-31, List 11-12; Rezi, 2011; Hansen, 2005), weight systems are much harder to prove. In several cases a standardization of fragments can be substantiated within single hoards (cf. Ciugudean et al., 2006: 46-49), while systems consistent throughout larger regions seem to fail to appear (Hansen, 1994: 378-79). Anyway, Sommerfeld's basic idea of the value of raw material as a gift to the gods remains a viable approach to fragmentation in hoards.

Hansen (1994: 360-63; 2005) on the other hand has substantiated the point that also in scrap hoards regionally and chronologically specific rules of selection are discernible. This does not only concern the object classes included. Throughout Europe there are only very few hoards in which more than one fragment of the same object appears (Hansen, 1994: 360), an observation hardly explainable by recycling. On a more theoretic level, S. Needham (2001) has argued for overcoming the sacred / utilitarian approach to hoard finds by allowing for 'flexible intentions' behind them and centring more on the social performances connected to (ritual) deposition. Within the 'flexible intentions' lies for him however also the possibility of recovery in certain social conditions; hoarding is seen ultimately as a method to regulate the metal stock available, although 'the great majority of finds would have been buried with some care, ceremony, and performance' (Needham, 2001: 294). J. Brück on the other hand has proposed an integrative view of fragmented objects and human remains in graves, settlements, and hoards. She proposes that the metallurgical circle of ore procurement, casting, object use, and recycling may be seen as a mirror of the human lifecycle, being facilitated by certain magical practices and rites de passage. Hoarded broken metalwork could then be a cultic metaphor for 'liminal states and points of transition in space and time' (Brück, 2006: 306).

Thus there are strong arguments suggesting that 'scrap' hoards should not be disregarded easily as a phenomenon different from the aesthetically pleasing complete things deposited in 'ritual' hoards. To further this argument, the Carpathian Basin, a region with an especially rich tradition of LBA 'scrap' hoards, will be chosen as a case study, and an apparently insignificant group of finds which frequently appears in those hoards will be in the focus of attention: socketed axes whose sockets were intentionally filled with fragmented metalwork.

\section{Scrap hoards of the Carpathian Basin}

Throughout the Carpathian Basin, in a small slice of time described as the horizon CincuSuseni in Romanian or Kurd in Hungarian terminology (equalling roughly the Central European phase Hallstatt (Ha) A, c. 1200-1050 BC), astonishingly big hoards formed of mostly fragmented or damaged objects, raw material and objects considerably older than the 
This is the author's post-print of an article publishes as: Oliver Dietrich, Learning from 'scrap' about Late Bronze Age hoarding practices. A biographical approach to individual acts of dedication in large metal hoards. European Journal of Archaeology 17, 3 2014, 468-486. DOI 10.1179/1461957114Y.0000000061

average, sometimes dating back even to the Early Bronze Age (EBA), were deposited. Few of them have been published thoroughly, but especially a group of finds in Transylvania stands out due to the weights and numbers of objects. M. Rusu (1981) counted a total of 5812 objects weighing $1133 \mathrm{~kg}$ for the largest among them, the find of Uioara de Sus. Figure 1 gives the locations and numbers for the other finds making up this group, i.e. Aiud, Band, Bicaz I and II, Dipşa, Guşterița II and Şpălnaca II. As Rusu has stated, these eight finds contain more metal than all finds of the preceding period Bz D (in Central European terminology) taken together.

It is not surprising that these accumulations of broken objects and raw bronze, as well as smaller finds with similar composition, provoked interpretations along the lines of 'founder's hoards' early on. For the Carpathian Basin, this view can be followed back to one of the earliest texts concerned exclusively with bronze finds, F. Müller's (1858) treaty on 'Die Bronzealterthümer, eine Quelle der älteren siebenbürgischen Geschichte'. Therein, he interpreted the Romanian hoard of Nou Săsesc, which is constituted of 20 predominantly fragmented objects and two pieces of ingots found in a pottery vessel, as a founder's hoard on the basis that one of the bronze ingots fits quite well into the vessel and was maybe cast in it (Müller, 1858: 344). This argument was contextual in nature (and today unfortunately hard to test as the vessel is lost) but already with the publication of the hoard of Guşterița II in 1872, nearly all the more theoretical arguments for 'founder's hoards' were in place (fragmented, 'useless' objects, high portion of raw material, and some objects, which were deposited as cast: Reissenberger, 1872: 35).

Much like in Western Europe, these arguments were also in southeastern Europe the basis for the interpretation of 'scrap' hoards for the years to come. They can be found in the two main studies on the subject by M. Rusu (1981) and A. Mozsolics (1984), while the wet versus dry discussion is nearly absent. Information on find circumstances is scarce (Soroceanu, 1995), and the Carpathian Basin was subjected to large-scale drainage projects which further obscure original deposition contexts. Interestingly, in his detailed description of the hoard from Guşterița, L. Reissenberger (1872: 35) also mentions a socketed axe, whose socket was filled with fragments (List 1, Nr. 17, Figure 2, 1). He used it as an argument in favour of a 'founder's hoard', as this would be 'a phenomenon which is known also today, to save space, in the process of re-melting and casting' (my translation). In fact, this socketed axe is a good starting point to explore the opposite pole of explanation.

\section{'Miniature Hoards'}

To explore the meaning of this axe and other similar finds, a closer inspection of their lifehistory is necessary. Judging from the pronounced asymmetry of its blade, the socketed axe from Guşterița II was clearly used for some time. Nevertheless it was functional when fragments of sickles and saws were introduced in its socket and fixed there by powerful hammer blows, which also produced a crack in the lower socket. The axe was exceptionally well finished after casting; no traces of the casting seams, the casting skin or the waster are visible. Few socketed axes received that degree of attention; most were only finished with regard to functionality (my observation while reviewing approximately 3500 axes from Romania).

Even fewer axes were treated in the process of hoarding like the one from Guşteriţa. Until now 28 socketed axes with fragments in their sockets are known from southeastern Europe (cf. List 1). Within one hoard this treatment is always restricted to a few pieces, for example only 5 of approximately 260 axes from the hoard of Uioara de Sus (List 1, Nr. 2529).

All of these axes share a biography of longer use as a tool, and an end of use-life marked by reworking into a container and deposition. In some cases the axes were used 
This is the author's post-print of an article publishes as: Oliver Dietrich, Learning from 'scrap' about Late Bronze Age hoarding practices. A biographical approach to individual acts of dedication in large metal hoards. European Journal of Archaeology 17, 3 2014, 468-486. DOI 10.1179/1461957114Y.0000000061

without manipulations, in others they underwent considerable re-working, including fragmentation. A good example for the latter is an axe from Şpălnaca II (Figure 2, 6). Here, the socket mouth and the blade were removed; fragments of a sickle and a saw were introduced into the socket and fixed by hammer strikes. Hammer blows were also applied to one small side of the fragment, without obvious reason, as no considerable transformation of form was achieved. The most radical form of these object combinations are those where the fragment of the axe is so small that the socket can no longer serve as a container without being compressed by hammer blows (e.g. Dipşa, Figure 2, 2-3). Complete and fragmented axes have been used in approximately equal proportions (11 complete, 13 fragmented), damaged pieces are less frequent (4 cases).

As already stated above, the filling, or blocking, of the socket has often been seen as a prerequisite for re-smelting. This interpretation is highly arguable. What technical sense is there in placing small fragments into the socket of an axe but not to also break the axe itself, as is documented in nearly half of all cases? To reach an advantage in the sense of economizing fuel, the founder would have had to produce as big a surface as possible for the heat to strike. Instead a larger and more compact object was produced which would have been considerably more resistant to the heat of the furnace. If the scope was to save space, a simple blow to the socket would have done the job far better than objects sticking out of the axe. Further, it is highly doubtful whether fragmentation really facilitates the process of resmelting. Several ingots with fragments sticking out speak against this assumption, and there are also cases known in which complete objects were subjected to re-smelting (Primas, 1981: 370). And finally, if the process of filling up sockets with fragments was due to metallurgical reasons, then why was it applied only to a small percentage of axes in the presumed 'founder's hoards', objects which are also frequently characterised by a particularly careful finish after casting?

A first insight can be gained from a consideration of regions in which socketed axes were not very common or not used at all. Here, winged axes can be found which were treated in a very similar way (Hansen, 1996-1998: 21, 25). Fixing objects between the wings on one side of an axe can hardly be explained by technical needs, as it does not imply any advantage in the re-smelting process. It seems on the contrary that ways were sought to combine objects securely inside larger hoards, as the hammer strikes on many axe sockets imply.

As already indicated, the phenomenon is not restricted to the Carpathian Basin. Hansen (1996-1998) presented 38 examples of similarly treated socketed and winged axes from all over Europe. The number of socketed axes alone has now risen to more than 90 examples (Dietrich \& Mörtz, in prep.; Figure 3) $)^{1}$. Furthermore, there is also evidence for fragmented objects in socketed spear heads (Maier, 1981; Soroceanu \& Szabó 2001). The finds of socketed axes seem to follow the rhythm of hoarding of fragmented bronzes in Europe, as the southeastern European examples date mostly to the $13^{\text {th }} / 12^{\text {th }}$ century while the western ones cluster in the $10^{\text {th }} / 9^{\text {th }}$ century BC (Hansen, 1996-1998: 17-18). One would expect a technical necessity to be distributed more evenly in time and space.

However, there is one further and quite convincing argument against technological purposes. In several cases objects of materials other than bronze have been found in the sockets of axes. From the hoard of Debeli vrh in Slovenia there is a socketed axe filled with amber beads (List 1, Nr. 11); from the Hungarian hoard of Napkor (List 1, Nr. 21) a socketed axe filled with gold objects is known. A larger number of axes with gold objects in their sockets comes from the British Isles (for a complete list see Dietrich \& Mörtz, in prep.). These combinations prove beyond a doubt that re-smelting was not the scope of this find

\footnotetext{
1 The map Figure 3 is clearly biased towards southeastern and northwestern Europe. I have reviewed the socketed axes of Romania and adjacent areas for my $\mathrm{PhD}$ thesis, for the British Isles finds have been collected in Dietrich \& Mörtz, in prep. The absence of finds in Central Europe is caused by the predominant use of winged axes in this area.
} 
This is the author's post-print of an article publishes as: Oliver Dietrich, Learning from 'scrap' about Late Bronze Age hoarding practices. A biographical approach to individual acts of dedication in large metal hoards. European Journal of Archaeology 17, 3 2014, 468-486. DOI 10.1179/1461957114Y.0000000061

group, but the axes' sockets were deliberately transformed into vessels. This role as vessel did not only encompass fragments of bronze, gold or amber objects, but in a few cases also raw material such as tin or lead (List 1, Nr. 2, 14).

As a technological explanation for the filled sockets can obviously be ruled out, Hansen tentatively argued that the combinations could have been meant to document sacrifices of individuals in larger contexts and proposed the term 'miniature hoards' for the group (Hansen, 1996-1998: 22-23). Bigger hoards in his eyes may be constituted of several acts of dedication and have a long and multifaceted biography.

The object combinations clearly fit into the definition criteria for hoards, if the basic definition of at least two objects combined in a find that is not a grave or a settlement is taken as a starting point (Eggers, 1959: 264-68; Hansen, 1996-1998: 14). In fact, finds like the densely stuffed axes from Guşterita (List 1, Nr. 17, Figure 2, 1) do constitute time-specific hoard combinations. The same is true for Western Europe, where e.g. an axe from Sublaines, France was filled completely with seven fragments of two bracelets, an axe, a chisel, a knife, a tube and of unknown function (Hansen, 1996-1998: 25, Nr. 27, Figure 8, 1). Another axe from the Rhine at Mainz was sealed with a bung of oat or barley straw after fragments of an axe and a chisel were put into the socket (Hansen, 1996-1998: 23, 25, Nr. 15). Organic bungs may have also been placed in the southeast European axes whose sockets were not closed by hammer blows. It seems that to some degree the socket takes over the role of the clay vessels many hoards were deposited in (cf. Hansen, 1996-1998: 23). To produce a border, to show the togetherness of certain things seems to have been the intention.

However, the insight that blocking socketed axes is not a necessary step in the chaine opératoire of re-smelting bronze objects does not necessarily constitute an argument on the purpose of the find assemblages within which these specially treated axes are found. Theoretically, they could have ended up in utilitarian 'scrap' hoards for a wide variety of reasons. A way to test Hansen's theory is to try to integrate the object combinations into the larger framework of Bronze Age hoarding practices of the Carpathian Basin. As stated above, hoarding has been shown convincingly to be governed by rules specific to certain regions in certain periods of time. Thus not only objects have a biography or history of their own, but also social practices (Hansen, 2012: 29-36). An effort has to be made to re-integrate the blocked axes into this larger frame by searching for similar phenomena in earlier and later phases.

\section{Cultural translations: Re-integrating object combinations in the history of hoarding}

An attempt to identify earlier phenomena similar to the 'miniature hoards' leads to surprising results. There are quite a few combinations of objects in pre-Ha A hoards which resemble the fragment-filled sockets structurally in many ways. To name a few characteristic examples from Romania (comp. Figure 4), the gold rings of the Bz D hoard of Bătarci belonged originally to a chain, which was fixed in the loop of a socketed axe (Macrea \& Kacsó, 1972: 101). The contemporaneous hoard from Crăciuneşti contains a bronze bar which is fixed to a bracelet (Nistor \& Vulpe, 1974: Figure 4, 29). From the slightly later hoard of Crasna Vişeului there is a socketed axe in whose loop a ring was fixed, which again is connected to a casting core for socketed spearheads (Kacsó, 1996: Figure 2). The Bz D hoard of Gheja is made up of a socketed axe and a chain of bronze rings fixed to its loop (Roska, 1942: 158, Nr. 84, Figure 182, 161, Nr. 91).

These older object combinations are in many ways comparable to the filled socketed axes. They also form a small subgroup, often inside larger hoards, they appear in small numbers and a metallurgical reason for the combinations is highly unlikely. Also, the combination of bronzes with more valuable metals reappears. If one tries to integrate the 
This is the author's post-print of an article publishes as: Oliver Dietrich, Learning from 'scrap' about Late Bronze Age hoarding practices. A biographical approach to individual acts of dedication in large metal hoards. European Journal of Archaeology 17, 3 2014, 468-486. DOI 10.1179/1461957114Y.0000000061

apparently unusual objects in the outlines of regional Bronze Age hoarding practices, a quite coherent picture emerges (compare Figure 5).

From the Early and Middle Bronze Age (MBA) of the Carpathian Basin relatively few hoards are known. The finds contain a very limited and canonical range of objects, mostly weapons and personal ornaments, while tools are largely missing (e.g. Mozsolics, 1967; David, 2002; Vachta, 2008; Soroceanu, 2012). The highly selective rules of hoarding are matched by the individuality of the objects. Axes and swords are individualized through complicated and distinct ornamentation. The hoards are small; most of them contain around 10 objects, while the largest rise to around 30. The small amount of objects included, their individuality and matching numbers of weapons and ornaments suggest personal endowments of warriors. Individuality seems to be a key concept for large parts of this period. Regional studies show the landscape divided in small-scale settlement clusters around hill-forts or tell sites (Dietrich 2010; Gogâltan, 2008). Hoards seem to have played an important role in marking and dividing the territories (Dietrich, 2010). In this period, object combinations are largely absent from hoards with the exception of golden rings, most often lock rings, which are frequently found arranged into bundles or chains (e.g. Hänsel \& Weihermann, 2000). These may well have been the most valuable offerings in a find, and maybe the individual sacrificing them wanted to emphasize the togetherness of the important gift beyond doubt.

At the beginning of the LBA (Bz D), the hoarding customs change abruptly. The hoard finds become not only considerably larger, but also the rules regarding the objects included become somehow less selective, the finds are much more heterogeneous (Mozsolics, 1973; Petrescu-Dîmbovița, 1978; Hansen, 1994; Bratu, 2009). With sickles and socketed axes, tools now form the backbone of the finds, and raw material makes its appearance for the first time. Find combinations which could be interpreted as 'personal' are very scarce; the finds betray the impression of collective offerings of larger groups. It is exactly in this moment of deindividualization that combinations of (complete) objects appear and mark the togetherness of certain things inside the finds. As the objects do not belong together on a functional level, this display of togetherness seems to aim more likely at pronouncing the individuality of a gift, which is enclosed in a larger context.

The drastic alterations in hoarding customs are hard to explain. In Bz D processes of change are visible throughout the Carpathian Basin. In its eastern part, the regionally welldefined cultural blocks of the MBA undergo processes of unification of the material culture and social organization with the appearance of the so-called Noua-Sabatinovka-Coslogeni cultural complex. The central settlements disappear and are substituted by a pattern of loosely scattered sites (Dietrich, in print). In the western regions of the Carpathian Basin however, the period could already see the start of new and very large centralized settlements (Szentmiklosi et al., 2011: 834-37) after the disappearance of tell-sites in the later MBA (Gogăltan, 2008: 40-41). How these processes may relate to each other and to changes in hoarding has yet to be clarified.

In Ha A the hoarding customs change again (Mozsolics, 1985; Petrescu-Dîmbovița, 1978; Hansen, 1994; Bratu, 2009). The finds become highly complex in their composition and, as mentioned above, very large with high percentages of raw material. Most things are now deposited in a damaged or fragmented state. In those highly complex, on the first look unstructured finds appear the fragment-filled socketed axes.

With the earlier object combinations in mind it now becomes clear that this is no new development at all, but a cultural translation of an older hoarding scheme into period-specific forms of expression. Instead of complete objects, fragments are now combined. The collection of fragments in an axe's socket can be understood as a process of reduction of the earlier combinations of complete objects. In a final stage the vessel itself is dissolved into a fragment. A development from complete, functional objects as a gift to the gods towards pars pro toto signs or symbols for a complete gift or hoard is discernible. This hypotheses also fits 
This is the author's post-print of an article publishes as: Oliver Dietrich, Learning from 'scrap' about Late Bronze Age hoarding practices. A biographical approach to individual acts of dedication in large metal hoards. European Journal of Archaeology 17, 3 2014, 468-486. DOI 10.1179/1461957114Y.0000000061

well with the fact that in most cases only one fragment of an object entered a hoard (Hansen, 1994: 360). Also in their most reduced form the fragment combinations remain a sign for a complete hoard and allow the sending of a message with similar content while using considerably less material. They are in this respect similar to purpose-made votive objects without practical function, and may be called a LBA religious innovation.

The phase $\mathrm{Ha} \mathrm{A}$ in the Carpathian Basin witnesses the start of a second unification process of material culture, which is even wider spread than the earlier one - the appearance of the so-called fluted ware (the following after Dietrich, in print). In the wake of these changes, large fortified settlements like Corneşti or Sântana in the Romanian Banat thrive (e.g. Szentmiklosi et al., 2011) together with sites which have the character of supra-regional meeting places. Inside a cluster of mounds at Lăpuş in Romania, monumental buildings with central hearths and intentionally destroyed pottery were recently discovered. These buildings are interpreted as places for large-scale feasting in connection with burial rites (MetznerNebelsick et al., 2010). It has been proposed that the large 'scrap' hoards may hint at sanctuaries/cult places as focal points in a network of cultic and profane central places (Dietrich, in print). Further research is needed to get a clearer image of these processes.

In the immediately following period $\mathrm{Ha} \mathrm{B}$, which is still characterized by the same, homogenous pottery style, the number of hoards and their volume again decrease (PetrescuDîmbovița, 1978; Mozsolics, 2000), while the selection rules for offerings become stricter. Again there are hoards which could represent individual endowments. To cite just a few examples, again taken from Romania, at Prejmer in 1871 a hoard composed of a solid-hilted sword, two spearheads and one socketed axe was discovered (Petrescu-Dîmboviţa, 1978: 138, Nr. 203); the second hoard of Predeal contained a sword, a fragment of a knife and a richly decorated socketed axe (Petrescu-Dîmboviţa, 1978: 138, Nr. 202); the hoard of Brad is made up of a spearhead, two bracelets and a socketed axe (Roska, 1942: 50, Nr. 202). In the last case the objects' interconnection is additionally pronounced by similar decorations, but all hoards betray the impression of personal belongings of warriors.

What leads to this return to older rules remains unclear for the moment; whatever the case, the new hoard type introduced in Ha A does not disappear completely, as is testified by finds with broken and damaged objects, as well as raw material like the hoard of Dezmir (Rusu et al., 1977: R 65a-d), which are clearly reduced reflections of the earlier large 'scrap' hoards. At Dridu, south of the Carpathian bow, one of these late 'scrap hoards' was found in a settlement (Enăchiug, 1995), which also produced the latest example of a 'filled' socketed axe (List 1, Nr. 16). Otherwise, in Ha B, object combinations largely diminish; finds like the socketed axe from Suatu (Rusu et al., 1977: R 67b, 18; Figure 4, 4) with a fragment of a bronze ring in its loop are scarce and also reminiscent of earlier traditions. In the course of $\mathrm{Ha}$ $\mathrm{B}$, a trend towards miniaturization is discernible for example for socketed axes (e.g. König, 2004: 36, Figure 5), leading to clearly non-functional forms. Miniaturization seems to replace fragmentation to some degree as an attribute of votive objects.

\section{Consequences for the interpretation of Late Bronze Age scrap hoards}

To sum up, axes with filled sockets can be understood as a cultic phenomenon when reintegrated into the history of hoarding. They are part of a chain of similar occurrences attestable already from the EBA / MBA on. Object combinations, whether in form of whole or fragmented things, seem to appear in phases when hoards become more collective in nature, while they diminish or are restricted to certain special object classes in phases when personalized hoards are attested. Fragmentation is a generalized phenomenon in hoards of certain periods and may be interpreted as a process of abstraction from complete gifts to the gods towards pars pro toto signs, and at least in the Carpathian Basin, miniaturized votive 
This is the author's post-print of an article publishes as: Oliver Dietrich, Learning from 'scrap' about Late Bronze Age hoarding practices. A biographical approach to individual acts of dedication in large metal hoards. European Journal of Archaeology 17, 3 2014, 468-486. DOI 10.1179/1461957114Y.0000000061

objects. The fragment-filled socketed axes are thus not a unique and strange phenomenon, but a cultural and time-specific translation of long-standing forms of religious expression.

Rather than being an argument against a cultic role of 'scrap' hoards, the object combinations, or 'miniature hoards', are proof in favour of these large accumulations of metal forming part of the rhythm of Bronze Age hoarding as a religiously motivated social practice. If fragments can be seen as signs for whole objects and combinations as symbols for complete hoards, an interpretation of depositions of whole objects and 'scrap' hoards in terms of a sacral / profane or gift / commodity dichotomy seems inadequate. Fragmentation does not strip objects of their meaning, but creates new meaning instead.

\section{List 1. Fragment-filled socketed axes in southeastern Europe}

1-2. Aiud, județ Aiud, RO. Hoard, Ha A. Socketed axe with unidentified fragments (ingots?); fragmented socketed axe filled with lead. Unpublished (Museum Aiud 7855; 7957). 3. Bakóca, Baranya megye, HU. Hoard, Ha A. Socketed axe with sickle (Hansen, 1996-1998: 25, Nr. 3). 4. Banat. Circumstances of discovery unknown. Socketed axe with sheet metal fragments. Unpublished (Museum Timişoara 6141). 5-6. Bogdan Vodă, jud. Maramureş, RO. Hoard, Ha A. Damaged socketed axe with a bracelet (Figure 2, 5); fragment of a socketed axe with unidentified bronze fragments (needle?) (Motzoi-Chicideanu \& Iuga, 1995: 143, Nr. 26, Plate 2, 11; 144, Nr. 37, Plate 2, 21). 7. Breaza, județ Mureş, RO. Hoard, Ha A. Fragment of a socketed axe with two folded bronze sheets (saws?) (Rezi, 2011 Plate 2, 6). 8. Cenad, jud. Timiş, RO. Hoard, Ha A. Damaged socketed axe with unidentified objects (PetrescuDîmboviţa, 1978: 137, Nr. 194, Plate 216B, 1). 9-10. Cugir, județ Alba, RO. Hoard, Ha A. Fragment of a socketed axe with sheet metal; fragment of a socketed axe with bronze bar (Petrescu-Dîmbovița, 1977: Plate 134, 15, 18). 11. Debeli vrh, občina Črnomelj, Sl. Hoard, Bz D / Ha A. Socketed axe with 13 amber beads and 4 bronze tubes (Hansen, 1996-1998: 19). 12-14. Dipşa, jud. Bistrița-Năsăud, RO. Hoard, Ha A. Fragment of a socketed axe with several fragments (a needle, an ingot and sheet metal identifiable; Figure 2, 3); fragment of a socketed axe with ingot fragments (Figure 2,2); socketed axe filled with a blue metallic oxide (tin?) (Ciugudean et al., 2006: 21, Nr. 169, Plate XXV, 1; 21, Nr. 167, Plate XXIV, 2; 20, Nr. 142, Plate XVIII, 2). 15. Dolina, Brod-Posavina županija, HR. Hoard, Bz D / Ha A. Socketed axe with ingot (Hansen, 1996-1998: 25, Nr. 6). 16. Dridu, jud. Ialomiţa, RO. Settlement find, Ha B. Socketed axe with seven fragments, inter alia a knife (Renţa, 2008: 101, Fig. 67/8). 17. Guşterița II, jud. Sibiu, RO. Hoard, Ha A. Socketed axe with sickles and saws (Figure 2, 1; Hansen, 1996-1998: 25, Nr. 1). 18. Klenje, Mačva, RS. Hoard. Socketed axe with bracelet and dagger (Hansen, 1996-1998: 25, Nr. 5). 19. Lăţunaş, jud. Timiş, RO. Hoard. Socketed axe with bracelet and ingot (Figure 2, 4; Hansen, 1996-1998: 25, Nr. 2). 20. Moravia or Upper Hungary. Circumstances of discovery unknown. Socketed axe with socketed axe (Hansen, 1996-1998: 25, Nr. 7). 21. Napkor-Piripucpuszta, Szabolcs-Szatmár-Bereg megye, HU. Hoard. Bz D / Ha A. Socketed axe with six small gold objects (Hansen, 1996-1998: 19). 22. Pamuk, Somogy megye, HU. Hoard, Ha A. Fragment of a socketed axe with bronze wire (Hansen, 1996-1998: 25, Nr. 4). 23. Rozavlea III, jud. Maramureş, RO. Hoard, Bz D. Damaged socketed axe with unidentified fragments (Kacsó \& Mitrea, 1976: Figure 1, 15). 24. Şpălnaca II, jud. Alba, RO. Hoard, Ha A. Fragment of a socketed axe with sickle and saw. Unpublished (Museum Aiud 266; Figure 2, 6). 25-29. Uioara de Sus, jud. Alba, RO. Hoard, Ha A. Fragment of socketed axe with ingot; damaged socketed axe with bracelet; fragment of a socketed axe with ingot; fragment of a socketed axe with needle and ingot; fragment of a socketed axe with socketed axe and sickle(?). Unpublished (Museum Cluj-Napoca III 4928; III 4936; III 4962; III 5058; III 5238). 30. Zlatna III, jud. Alba, RO. Hoard, Ha A. Fragment of a socketed axe with bracelets(?). Petrescu-Dîmboviţa, 1978: 135, Plate 211A, 6. 
This is the author's post-print of an article publishes as: Oliver Dietrich, Learning from 'scrap' about Late Bronze Age hoarding practices. A biographical approach to individual acts of dedication in large metal hoards. European Journal of Archaeology 17, 3 2014, 468-486. DOI 10.1179/1461957114Y.0000000061

\section{Acknowledgements}

I would like to thank Laura Dietrich, Svend Hansen, Tobias Mörtz and two anonymous reviewers for comments on earlier versions of this text. First-hand inspection of the Romanian socketed axes discussed here was possible due to a scholarship of the German Academic Exchange Service (DAAD), and the kind permission and help of Horia Ciugudean, Alba Iulia, Viorica Crişan, and Mihai Rotea, Cluj-Napoca, Carol Kacsó, Baia Mare, Sabin Adrian Luca, Sibiu, Paul Scrobotă, Matilda Takács, and Marcela Vintilă, Aiud, and Alexandru Szentmiklosi, Timişoara. Thanks are due to Lee Clare for language corrections. Last but not least I want to thank the EAA for awarding this paper with the EAA Student Award.

\section{References}

Boas, F. 1925. Contributions to the ethnology of the Kwakiutl. New York: Columbia University Press.

Bourdieu, P. 2012. Entwurf einer Theorie der Praxis auf der ethnologischen Grundlage der kabylischen Gesellschaft. Frankfurt am Main: Suhrkamp.

Bradley, R. 1990. The passage of arms: an archaeological analysis of prehistoric hoards and votive deposits. Cambridge: Cambridge University Press.

Bradley, R. 2013. 'Hoards and the deposition of metalwork'. In: H. Fokkens and A. Harding, eds. The Oxford handbook of the European Bronze Age. Oxford: Oxford University Press, pp. 121-39.

Brandherm, D. 2004. Ein neuer Fund eines Langquaidbeiles und einer Lanzenspitze aus Speyer. Zum Beginn und zur Deutung der Brucherzdeponierungssitte in Süddeutschland. Archäologisches Korrespondenzblatt, 34: 357-74.

Bratu, O. 2009. Depuneri de bronzuri între Dunărea Mijlocie şi Nistru în secolele XIII-VII a. Chr. Bucureşti: Renaissance.

v. Brunn, W. A. 1980. Eine Deutung spätbronzezeitlicher Hortfunde zwischen Elbe und Weichsel. Bericht der Römischen-Germanischen Kommission, 61: 91-150.

Burkert, W. 1998. Kulte des Altertums. Biologische Grundlagen der Religion. München: Beck.

Brück, J. 2006. Fragmentation, personhood and the social construction of technology in Middle and Late Bronze Age Britain. Cambridge Archaeological Journal 16 (3): 297-315.

Childe, V.G. 1930. The Bronze Age. Cambridge: Cambridge University Press.

Ciugudean, H., Luca, S.A. \& Georgescu A. 2006. Depozitul de bronzuri de la Dipşa. Alba Iulia: Altip.

Chapman, J. 2000. Fragmentation in archaeology: people, places and broken objects in the prehistory of south-eastern Europe. London: Routledge. 
This is the author's post-print of an article publishes as: Oliver Dietrich, Learning from 'scrap' about Late Bronze Age hoarding practices. A biographical approach to individual acts of dedication in large metal hoards. European Journal of Archaeology 17, 3 2014, 468-486. DOI 10.1179/1461957114Y.0000000061

Čivilyté, A. 2009. Wahl der Waffen. Studien zur Deutung der bronzezeitlichen Waffendeponierungen im nördlichen Mitteleuropa. Bonn: Habelt.

David, W. 2002. Studien zu Ornamentik und Datierung der bronzezeitlichen Depotfundgruppe Hajdúsámson-Apa-Ighiel-Zajta. Alba Iulia: Altip.

Dietrich, L. 2010. Eliten der frühen und mittleren Bronzezeit im südöstlichen Karpatenbecken. Prähistorische Zeitschrift, 85: 191-206.

Dietrich, L. in print. A new world order: the spread of the fluted ware in the Late Bronze Age and Early Iron Age in the Carpathian Basin. In: P. Suchowska-Ducke and H. Vandkilde, eds. Mobility of culture in Bronze Age Europe. Proceedings of an international conference and the Marie Curie ITN 'Forging Identities' at Aarhus University June 2012. Oxford: Hadrian Books.

Dietrich, O. \& Mörtz, T. in prep. Sockets full of scrap? Remarks on deliberate fragmentation in Late Bronze Age metal deposits in south-eastern and north-western Europe. In: A. BlancoGonzález and J.C. Chapman, eds. Deliberate fragmentation revisited. Assessing social and material agency in the archaeological record. In preparation.

Eggers, H.J. 1959. Einführung in die Vorgeschichte. München: Piper.

Enăchiug, V. 1995. Enăchiug, Der Bronzefund von Dridu, Kr. Ialomiţa. In: T. Soroceanu, ed. Bronzefunde aus Rumänien. Berlin: Spiess. pp. 279-310.

Evans, J. 1881. The ancient bronze implements, weapons, and ornaments of Great Britain and Ireland. London: Longmans, Green \& Co.

Fontijn, D.R. 2002. Sacrificial landscapes. Cultural Biographies of persons, objects and 'natural' places in the Bronze Age of the southern Netherlands. Leiden: University of Leiden.

Geißlinger, H. 1984. Depotfund, Hortfund. In: Reallexikon der Germanischen Altertumskunde 5. Berlin \& New York: De Gruyter, pp. 220-28.

Geißlinger, H. 2004. Nichtsakrale Moordepots - dänische Beispiele aus der frühen Neuzeit. Germania, 82 (2): 459-89.

Godelier, M. 1999. Das Rätsel der Gabe. Geld, Geschenke, heilige Objekte. München: Beck.

Gogâltan, F. 2008. Fortified Bronze Age tell settlements in the Carpathian Basin. A general overview. In: J. Czebreszuk, S. Kadrow and J. Müller, eds. Defensive structures from Central Europe to the Aegean in the $3^{\text {rd }}$ and $2^{\text {nd }}$ millennia BC. Bonn: Habelt, pp. 39-56.

Hänsel, B., 1997. Gaben an die Götter - Schätze der Bronzezeit Europas - eine Einführung. In: A. Hänsel and B. Hänsel, eds. Gaben an die Götter. Schätze der Bronzezeit Europas. Berlin: Museum für Vor- und Frühgeschichte, pp. 11-22.

Hänsel A. \& Hänsel B. eds. 1997. Gaben an die Götter. Schätze der Bronzezeit Europas. Berlin: Museum für Vor- und Frühgeschichte. 
This is the author's post-print of an article publishes as: Oliver Dietrich, Learning from 'scrap' about Late Bronze Age hoarding practices. A biographical approach to individual acts of dedication in large metal hoards. European Journal of Archaeology 17, 3 2014, 468-486. DOI 10.1179/1461957114Y.0000000061

Hänsel, B. \& Weihermann, P. 2000. Ein neu erworbener Goldhort aus dem Karpatenbecken im Berliner Museum für Vor- und Frühgeschichte. Acta Praehistorica et Archaeologica, 32: 7-29.

Hansen, S. 1994. Studien zu den Metalldeponierungen während der älteren Urnenfelderzeit zwischen Rhônetal und Karpatenbecken. Bonn: Habelt.

Hansen, S. 1996-1998. Migration und Kommunikation während der späten Bronzezeit. Die Depots als Quelle für ihren Nachweis. Dacia N.S., XL-XLII: 5-28.

Hansen, S. 2005. Über bronzezeitliche Horte in Ungarn - Horte als soziale Praxis. In: B. Horejs, R. Jung, E. Kaiser and B. Teržan, eds. Interpretationsraum Bronzezeit. Bernhard Hänsel von seinen Schülern gewidmet. Bonn: Habelt, pp. 211-30.

Hansen, S. 2012. Bronzezeitliche Horte: Zeitliche und räumliche Rekontextualisierungen. In: S. Hansen, D. Neumann and T. Vachta, eds. Hort und Raum. Aktuelle Forschungen zu bronzezeitlichen Deponierungen in Mitteleuropa. Berlin: De Gruyter, pp. 23-48.

Hansen, S., Neumann D. \& Vachta, T. eds. 2012. Hort und Raum. Aktuelle Forschungen zu bronzezeitlichen Deponierungen in Mitteleuropa. Berlin: De Gruyter.

Hundt, H.-J. 1955. Versuch zur Deutung der Depotfunde der nordischen jüngeren Bronzezeit unter besonderer Berücksichtigung Mecklenburgs. Jahrbuch des Römisch-Germanischen Zentralmuseums Mainz, 2: 95-140.

Huth, C. 1997. Westeuropäische Horte der Spätbronzezeit. Regensburg: Universitätsverlag.

Huth, C. 2008. Horte als Geschichtsquelle. In: K. Schmotz, ed. Vorträge des 26. Niederbayerischen Archäologentages. Rhaden: Leidorf: pp. 131-62.

Kacsó, C. 1996. Der Bronzefund von Crasna Vişeului. In: T. Kovács, ed. Studien zur Metallindustrie im Karpatenbecken und den benachbarten Regionen. Festschrift für Amália Mozsolics. Budapest: Magyar Nemzeti Múzeum, pp. 250-63.

Kacsó, C. \& Mitrea, I. 1976. Depozitul de bronzuri de la Rozavlea. Studii şi Cercetări de Istorie Veche şi Arheologie, 27: 537-48.

König, P. 2004. Spätbronzezeitliche Hortfunde aus Bosnien und der Herzegowina. Stuttgart: Steiner.

Kristiansen, K. 1996. Die Hortfunde der jüngeren Bronzezeit Dänemarks. Fundumstände, Funktion und historische Entwicklung. In: P. Schauer, ed.. Archäologische Forschungen zum Kultgeschehen in der jüngeren Bronzezeit und frühen Eisenzeit Alteuropas. Bonn: Habelt, pp. 255-70.

Macrea, M. \& Kacsó, C. 1972. Depozitul de bronzuri de la Bătarci. Studii şi Comunicări Satu Mare, 2: 101-11.

Maier, R.A. 1981. Nadeln und kleine Spitzen in Schäftungstüllen urgeschichtlicher Bronzewaffen oder Bronzegeräte. Germania, 59 (2): 393-95. 
This is the author's post-print of an article publishes as: Oliver Dietrich, Learning from 'scrap' about Late Bronze Age hoarding practices. A biographical approach to individual acts of dedication in large metal hoards. European Journal of Archaeology 17, 3 2014, 468-486. DOI 10.1179/1461957114Y.0000000061

Malim, T. 2010. The environmental and social context of the Isleham Hoard. Antiquaries Journal 90: 73-130.

Malinowski, B. 1922. Argonauts of the western Pacific. London: Dutton.

Maraszek, R. 2006. Spätbronzezeitliche Hortfundlandschaften in atlantischer und nordischer Tradition. Halle: Landesamt für Denkmalpflege und Archäologie Sachsen.

Mauss, M. 1990. Die Gabe. Form und Funktion des Austauschs in archaischen Gesellschaften. Frankfurt am Main: Suhrkamp.

Metzner-Nebelsick, C., Kacsó, C. \& Nebelsick, L.D. 2010. A bronze age ritual structure on the edge of the Carpathian Basin. Studii şi comunicări Satu Mare 26 (1): 219-34.

Motzoi-Chicideanu, I. \& Iuga, G. 1995. Der Bronzefund von Bogdan Vodă, Kr. Maramureş. In: T. Soroceanu, ed. Bronzefunde aus Rumänien. Berlin: Spiess. pp. 141-68.

Mozsolics, A. 1967. Bronzefunde des Karpatenbeckens. Depotfundhorizonte von Hajdúsámson und Kosziderpadlás. Budapest: Akadémiai Kiadó.

Mozsolics, A. 1973. Bronze- und Goldfunde des Karpatenbeckens. Budapest: Akadémiai Kiadó.

Mozsolics, A. 1984: Ein Beitrag zum Metallhandwerk der ungarischen Bronzezeit. Bericht der Römisch-Germanischen Kommission, 65: 19-72.

Mozsolics, A. 1985. Bronzefunde aus Ungarn. Depotfundhorizonte von Aranyos, Kurd und Gyermely. Budapest: Akadémiai Kiadó.

Mozsolics, A. 2000. Bronzefunde aus Ungarn. Depotfundhorizonte von Hajdúböszörmény, Románd und Bükkszentlászló. Kiel: Verlag Dieter Voges.

Müller, F. 1858. Die Bronzealterthümer, eine Quelle der älteren siebenbürgischen Geschichte. Archiv des Vereins für Siebenbürgische Landeskunde, 3: 333-82.

Müller, S. 1886. Votivfund fra Sten- og Bronzealderen. Aarbøger, 1886: 216-50.

Needham, S. 2001. When expediency broaches ritual intention: the flow of metal between systemic and buried domains. Journal of the Royal Anthropological Institute, 7 (2): 275-98.

Needham, S. 2007. Bronze makes a Bronze Age? Considering the systemics of Bronze Age metal use and the implications of selective deposition. In C. Burgess, P. Topping and F. Lynch, eds. Beyond Stonehenge: essays on the Bronze Age in honour of Colin Burgess. Oxford: Oxbow Books, pp. 278-87.

Nistor, F. \& Vulpe, A. 1974. Depozitul de bronzuri de la Crăciuneşti (Maramureş). Studii şi Cercetări de Istorie Veche şi Arheologie, 25 (1): 5-18.

Petrescu-Dîmbovița, M. 1977. Depozitele de bronzuri din România. Bucharest: Editura Academiei. 
This is the author's post-print of an article publishes as: Oliver Dietrich, Learning from 'scrap' about Late Bronze Age hoarding practices. A biographical approach to individual acts of dedication in large metal hoards. European Journal of Archaeology 17, 3 2014, 468-486. DOI 10.1179/1461957114Y.0000000061

Petrescu-Dîmboviţa, M. 1978. Die Sicheln in Rumänien mit Corpus der jung- und spätbronzezeitlichen Horte Rumäniens. München: Beck.

Primas, M. 1981. Erntemesser der jüngeren und späten Bronzezeit. In: H. Lorenz, ed. Studien zur Bronzezeit. Festschrift für Wilhelm Albert v. Brunn. Mainz: Zabern, pp. 363-74.

Reissenberger, L. 1872. Der neueste archäologische Fund bei Hammersdorf. Archiv des Vereins für Siebenbürgische Landeskunde, 10: 8-37.

Renţa, E. 2008. Prima epocă a fierului pe cursul râului Ialomiţa. Târgovişte: Cetatea de Scaun.

Rezi, B. 2011. Voluntary Destruction and Fragmentation in Late Bronze Age Hoards from Central Transylvania. In: S. Berecki, R.E. Németh and B. Rezi, eds. Bronze Age Rites and Rituals in the Carpathian Basin. Cluj-Napoca: Mega, pp. 303-34.

Rittershofer, K.-F. 1983. Der Hortfund von Bühl und seine Beziehungen. Bericht der Römischen-Germanischen Kommission, 64: 139-415.

Roska, M. 1942. Erdély régészeti repertóriuma. I. Öskor. Cluj: Erdélyi Tudományos Intézet.

Rusu, M. 1981. Bemerkungen zu den großen Werkstätten- und Gießereifunden aus Siebenbürgen. In: H. Lorenz, ed. Studien zur Bronzezeit. Festschrift für Wilhelm Albert v. Brunn. Mainz: Zabern, pp. 375-402.

Rusu, M., Dörner, E., Pintea, V. \& Bader, T. 1977. Bronzehortfunde aus Transsilvanien (Ha A2-B3). Inventaria Archaeologica Rumänien, R 64-R 70.

Sommerfeld, C. 1994. Gerätegeld Sichel. Studien zur monetären Struktur bronzezeitlicher Horte im nördlichen Mitteleuropa. Berlin \& New York: De Gruyter.

Soroceanu, T. 1995. Die Fundumstände bronzezeitlicher Deponierungen - Ein Beitrag zur Hortdeutung beiderseits der Karpaten. In: T. Soroceanu, ed. Bronzefunde aus Rumänien. Berlin: Spiess. pp. 15-80.

Soroceanu, T. 2012. Die Kupfer- und Bronzedepots der frühen und mittleren Bronzezeit in Rumänien. Cluj-Napoca \& Bistriţa: Accent.

Soroceanu, T. \& Szabó, J. J. 2001. Der Bronzefund von Gyula, Kom. Békés. Mora Ferenc Múzeum Evkönyve, Studia Archaeologica 7: 219-30.

Szentmiklosi, A., Heeb, B.S., Heeb, J., Harding, A., Krause, R. \& Becker, H. 2011. CorneştiIarcuri - a Bronze Age town in the Romanian Banat? Antiquity 85: 819-38.

Thomsen, C. J. 1843-1845. Om den nordiske oldtids broncearbeider. Antiquariske Tidsskrift, 1: 171-75.

Turner, L. 2010. A re-interpretation of the Later Bronze Age metalwork hoards of Essex and Kent. Oxford: Hadrian Books.

Vachta, T. 2008. Studien zu den bronzezeitlichen Hortfunden des oberen Theissgebiets. Bonn: Habelt. 
This is the author's post-print of an article publishes as: Oliver Dietrich, Learning from 'scrap' about Late Bronze Age hoarding practices. A biographical approach to individual acts of dedication in large metal hoards. European Journal of Archaeology 17, 3 2014, 468-486. DOI 10.1179/1461957114Y.0000000061

Wanzek, B. 1989. Die Gussmodel für Tüllenbeile im südöstlichen Europa. Bonn: Habelt.

Willroth, K.-H. 1985. Aspekte älterbronzezeitlicher Deponierungen im südlichen Skandinavien. Germania, 63: 361-400.

Worsaae, J.J.A. 1867. Sur quelques trouvailles de l'âge du bronze faites dans des tourbières. Kopenhagen: Kongelige Nordiske Oldskriftselskab.

Address: German Archaeological Institute, Orient Department, Podbielskiallee 69-71, 14195 Berlin [oliver.dietrich@dainst.de]

\section{Figures}

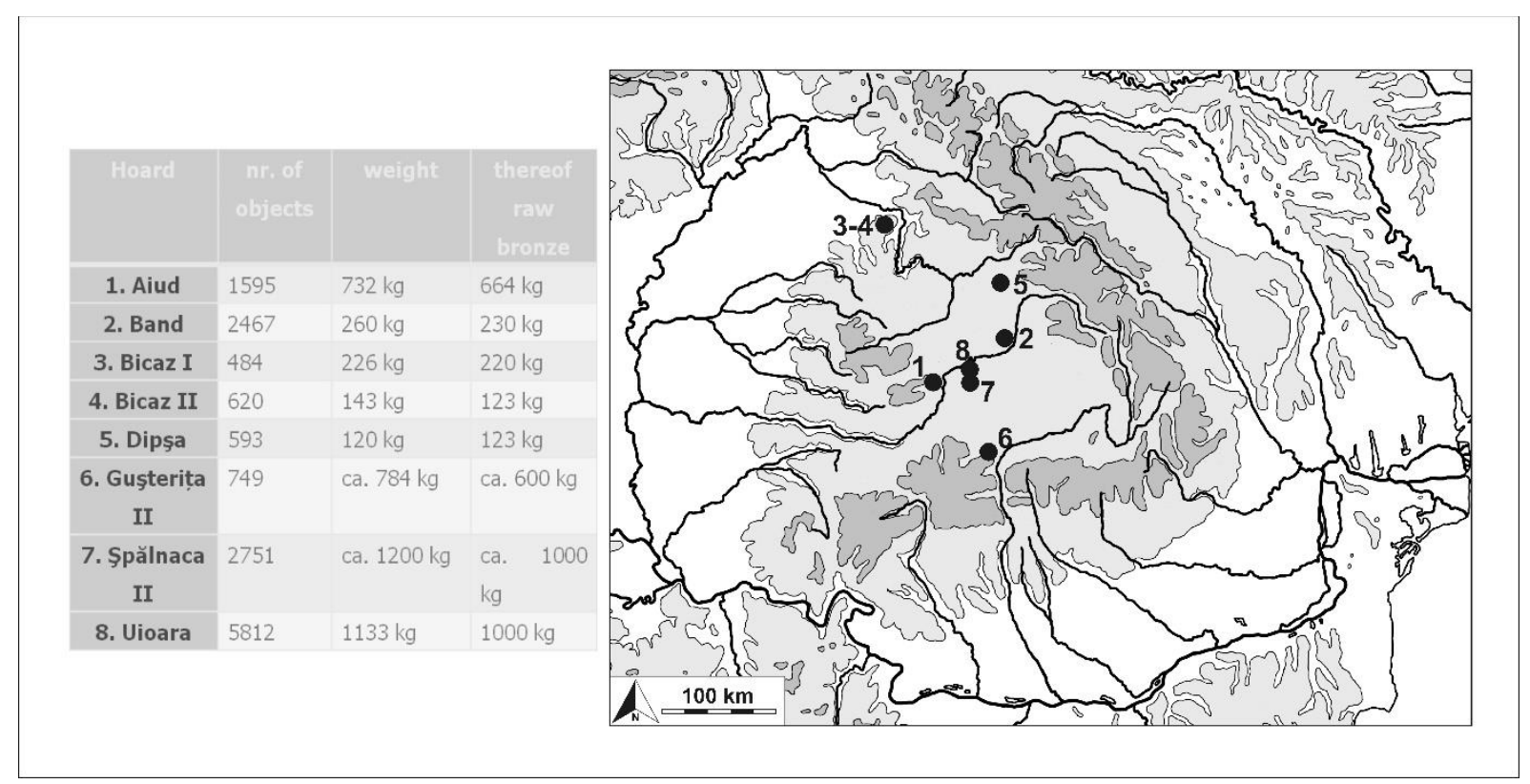

FIGURE 1 Size and location of the big Transylvanian „founder's hoards”. Numbers of objects and weights after Rusu (1981). 
This is the author's post-print of an article publishes as: Oliver Dietrich, Learning from 'scrap' about Late Bronze Age hoarding practices. A biographical approach to individual acts of dedication in large metal hoards. European Journal of Archaeology 17, 3 2014, 468-486. DOI 10.1179/1461957114Y.0000000061

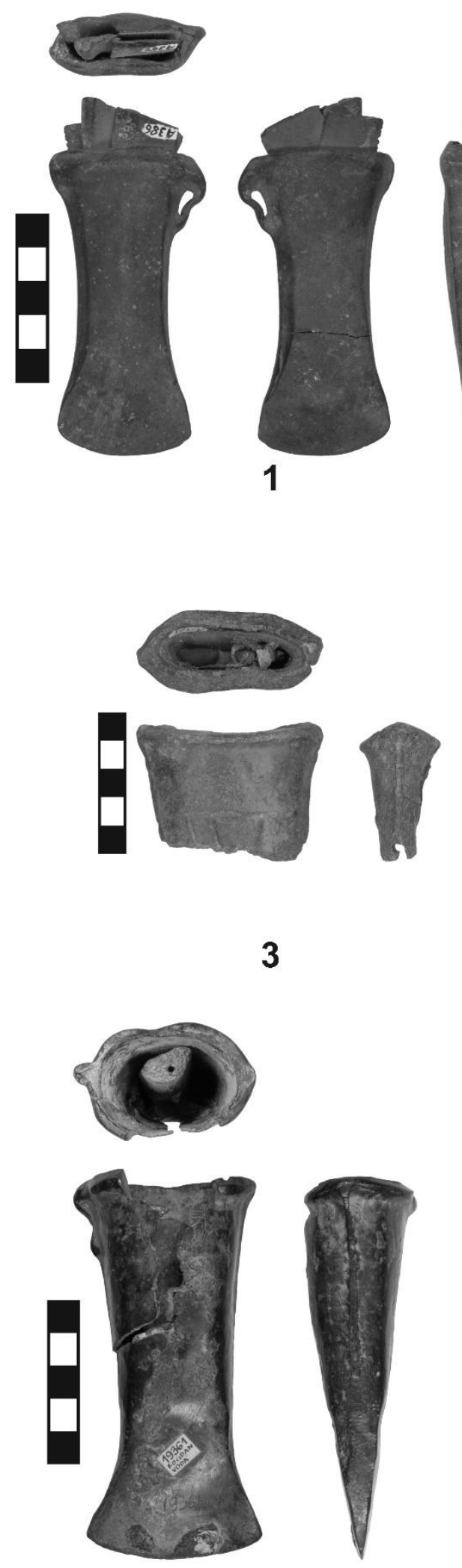

5
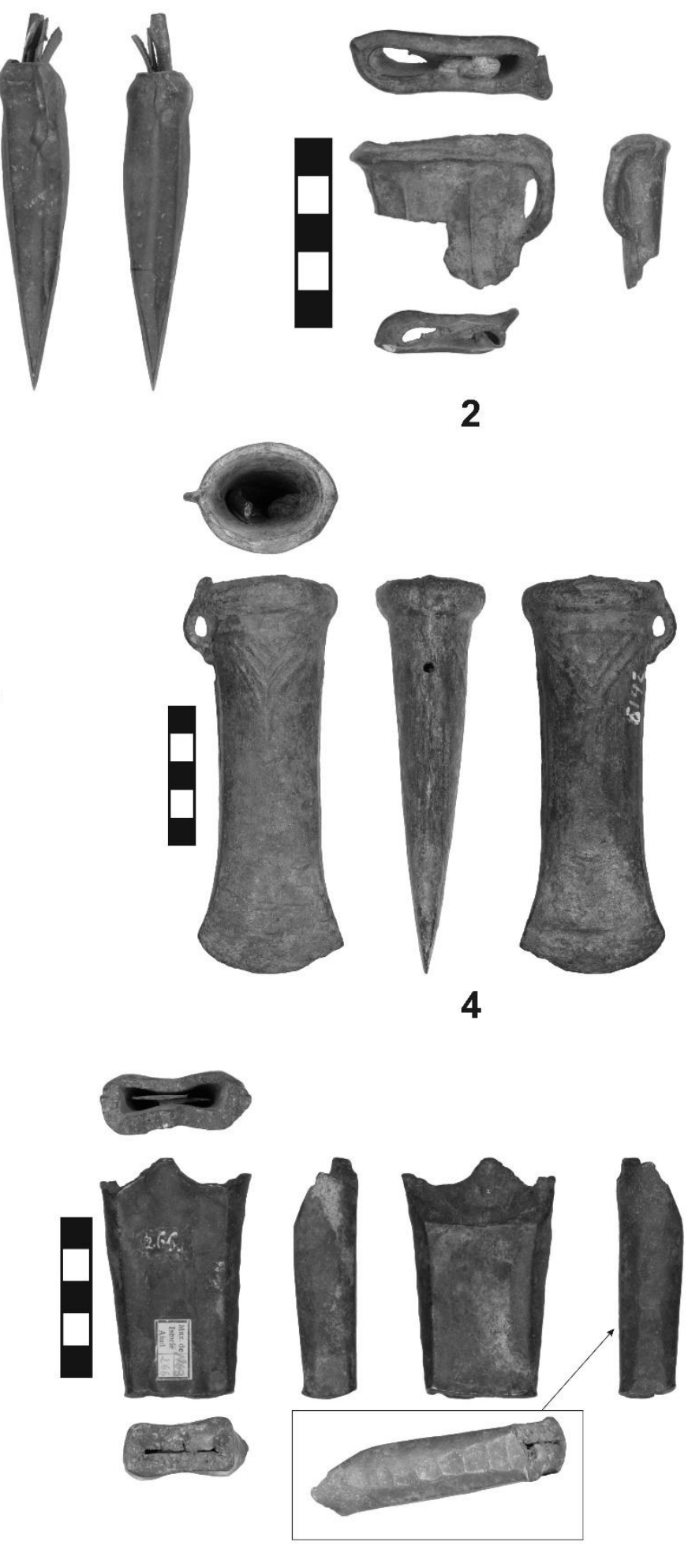

6

FIGURE 2 Socketed axes with fragment-filled sockets. 1 Guşteriţa II; 2-3 Dipşa; 4 Lăţunaş; 5 Bogdan Vodă; 6 Şpălnaca II. 
This is the author's post-print of an article publishes as: Oliver Dietrich, Learning from 'scrap' about Late Bronze Age hoarding practices. A biographical approach to individual acts of dedication in large metal hoards. European Journal of Archaeology 17, 3 2014, 468-486. DOI 10.1179/1461957114Y.0000000061

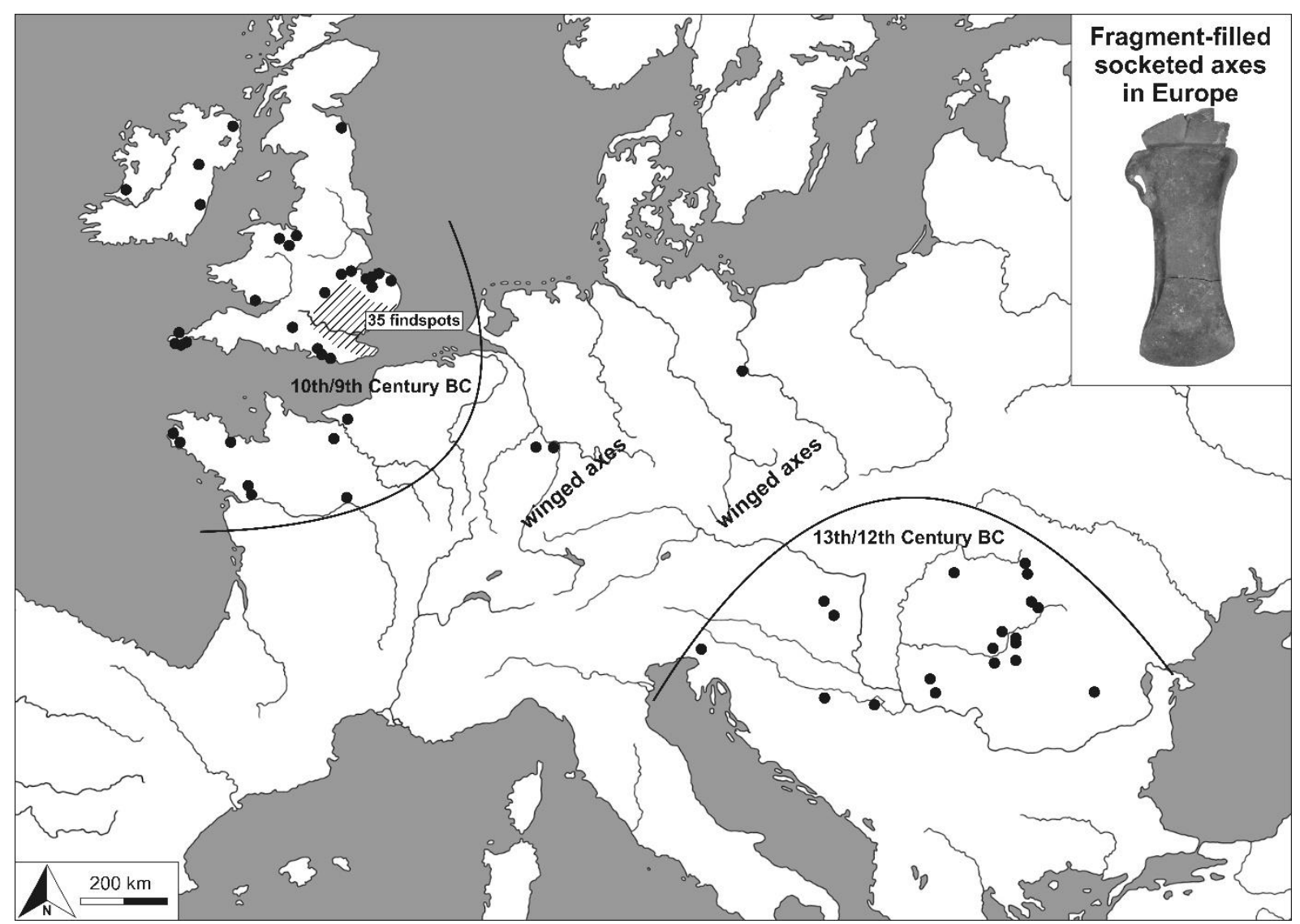

FIGURE 3 Distribution of fragment-filled socketed axes in Europe (based on lists in Dietrich \& Mörtz, in prep.). 
This is the author's post-print of an article publishes as: Oliver Dietrich, Learning from 'scrap' about Late Bronze Age hoarding practices. A biographical approach to individual acts of dedication in large metal hoards. European Journal of Archaeology 17, 3 2014, 468-486. DOI 10.1179/1461957114Y.0000000061
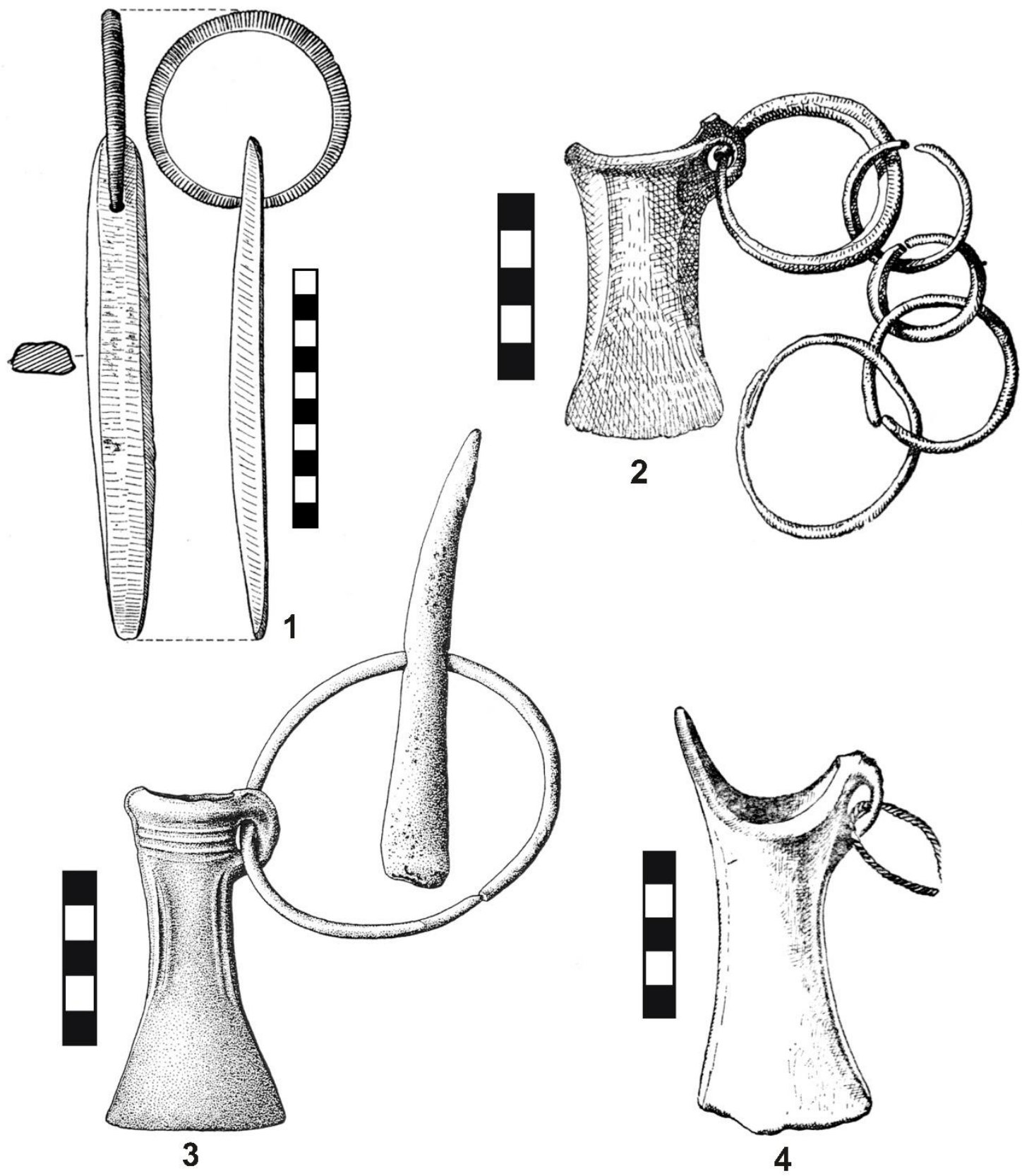

FIGURE 4 Combinations of complete Objects from the Carpathian Basin. 1 Crăciuneşti (after Nistor \& Vulpe, 1974, Fig. 4.29); 2 Gheja (after Roska 1942: Fig. 182); 3 Crasna Vişeului (after Kacsó 1996, Fig. 2.1; 4 Suatu (after Rusu et al., 1977: R67b.18). 
This is the author's post-print of an article publishes as: Oliver Dietrich, Learning from 'scrap' about Late Bronze Age hoarding practices. A biographical approach to individual acts of dedication in large metal hoards. European Journal of Archaeology 17, 3 2014, 468-486. DOI 10.1179/1461957114Y.0000000061

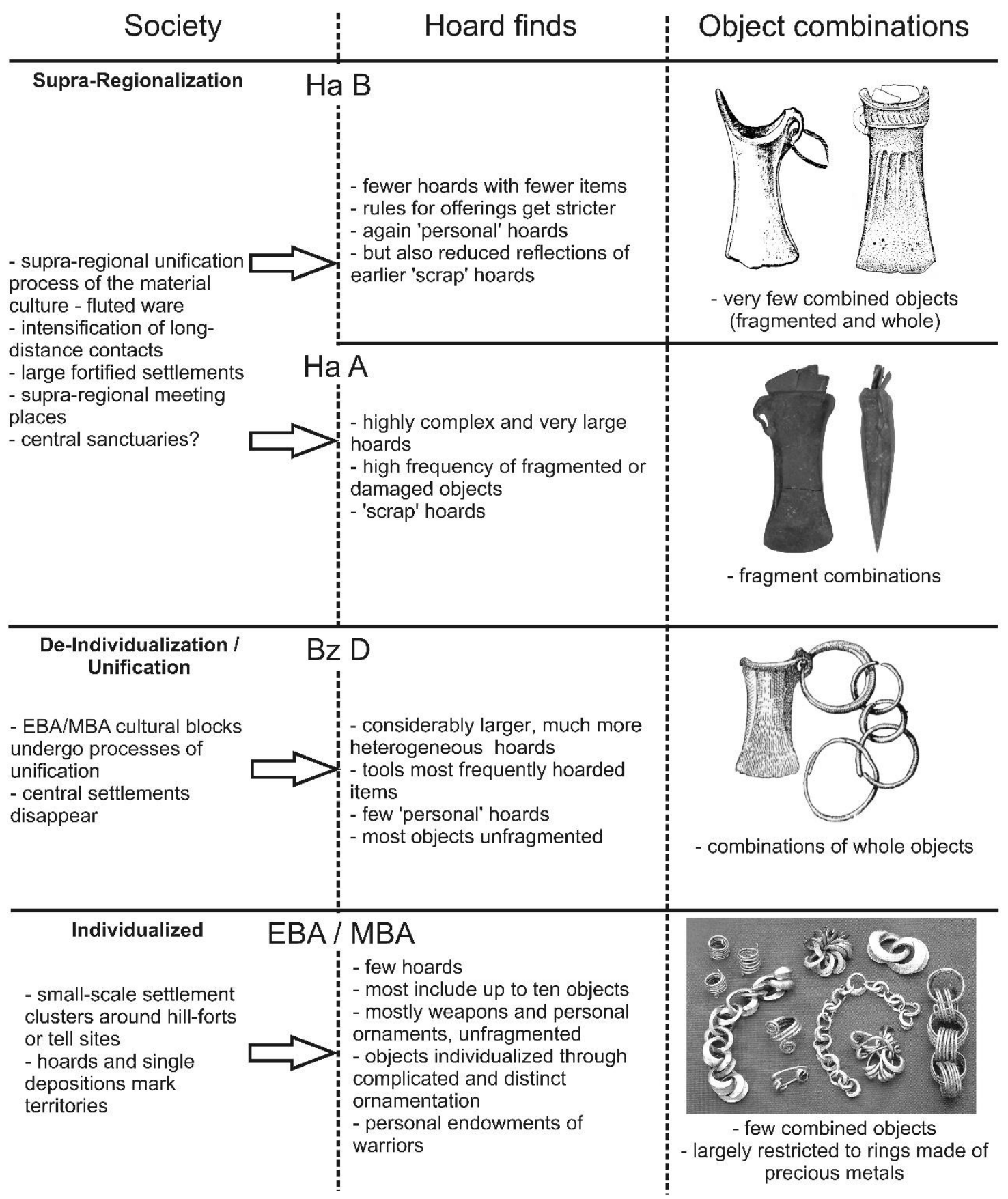

FIGURE 5 The integration of object combinations into the rhythm of hoarding in the Carpathian Basin (finds of Pécs after Hänsel \& Weihermann, 2000: Figure 1; of Gheja after Roska 1942: Fig. 182; of Suatu after Rusu et al., 1977: R67b.18; of Dridu after Rența 2008: Figure 67.8). 